\title{
多段吸収を用いた低温水吸収冷凍機の温水下限温度特性
}

\author{
江崎 秀司 ${ }^{* 1}$ ，小林 崇浩*2，大能 正之*3，金子 敏之*3

\section{Hot water lower limit temperature characteristics of hot water fired absorption chiller using multi-stage absorption} \\ Shuji ESAKI ${ }^{* 1}$, Takahiro KOBAYASHI ${ }^{* 2}$, Masayuki OHNOU*3 ${ }^{* 3}$ and Toshiyuki KANEKO*3 \\ ${ }^{* 1}$ Kagoshima National College of Technology, Dept. of Mechanical Engineering \\ 1460-1 Shinkou, Hayato-chou, Kirishima-shi, Kagoshima, 899-5193, Japan \\ ${ }^{* 2}$ Panasonic Corporation Appliances Company \\ 1-1-1 Sakata, Oizumi-machi, Oura-gun, Gunma, 370-0596, Japan \\ ${ }^{* 3}$ SOGA Iron Works
}

603-2 Higashishin-machi, Ota-shi, Gunma, 373-0015, Japan

\begin{abstract}
The design limits of a hot water fired absorption chiller in a cycle simulation were examined. The authors have already proposed how to determine the lowest limiting value of the smaller of the two temperature differences to get a logarithmic mean temperature difference when designing each element. This new algorithm was applied, based on the trend toward the hot water fired absorption chiller that employs a multi-stage absorption system. After performing a cycle simulation, the effects of stage number for the lowest hot water temperature that could be used in air conditioning were clarified. As a result, it was found that the limits of stage number were existed. It was also found that the lowest limiting temperature of hot water could be theoretically determined in the condition of the infinite-stage absorption system.
\end{abstract}

Received 18 October 2013

Key words : Absorption refrigerating machine, Refrigeration cycle, Simulation, Heat exchanger, Absorber, Evaporator, Condenser, Generator

\section{1. 緒 言}

今日，地球温暖化対策のために二酸化炭素の大幅な削減問題が話題になっていることから，さらなる低温レ心゙ ルの熱源利用が注目されてきている.フコン系の冷媒を用いない吸収冷凍機は排熱を利用して駆動するために化 石燃料の消費を削減できることから，地球規模の環境問題に大いに貢献できる空調機器であり，今後とも有効利 用されていくべきものと考えている.

これまで，単効用吸収冷凍機 (大園, 1980), (黒沢他, 1989) から一重二重効用吸収冷凍機 (斉藤他, 1994), (君島 他, 2000)，二重効用吸収冷凍機 (Vliet, et al., 1982), (飛原他, 1987), (斎藤他, 1996), (設楽, 2000), (川上他, 2004) さら には三重効用吸収冷凍機 (Kaita, 2002)，(井上他, 2003) まで数多くのサイクルシミュレーションの方法およびそ の結果が報告されている，著者らは吸収冷凍機を構成する蒸発器，吸収器，凝縮器および再生器の各要素におい て，それぞれの交換熱量を算出するために必要な対数平均温度差を与える二つの温度差のうち，值が小さくなる 温度差のほうに設計製造上可能な最小温度差を設定する限界設計手法を用いた新しいシミュレーションアルゴリ ズムを提案 (江崎他, 2011a) したほか，2 段吸収を導入したサイクルシミュレーションを行い, 利用可能な温水温 度を大幅に低減できることを報告 (江崎他, 2011b) した。

この空調に利用可能な温水温度は吸収器段数を増加させることによって，さらに低減することが可能であるこ とから, 吸収器段数が利用できる温水温度に及ぼす影響のほか, 吸収器を無限段数にした理論上利用可能な温水

No.13-00757 [DOI: 10.1299/transjsme.2014tep0152]

*1 正員，鹿児島工業高等専門学校（干899-5193 鹿児島県霧島市隼人町真孝 1460-1）

*2 パナソニック(株) (テ370-0596 群馬県邑楽郡大泉町坂田 1-1-1)

*3 (株) SOGA（厂373-0015 群馬県太田市東新町 603-2)

E-mail of corresponding authorl: esaki@kagoshima-ct.ac.jp 
の最低温度について検討しておくことは大変重要であり，本報告ではそれらをシミュレーションした結果につい て報告する。

\section{記 号}

$$
\begin{aligned}
& A \quad \text { ：伝熱面積 }\left[\mathrm{m}^{2}\right] \\
& C O P \text { : 成績係数 }[-] \\
& c_{P} \quad \text { : 定圧比熱 }[\mathrm{kJ} /(\mathrm{kg} \cdot \mathrm{K})] \\
& h \quad: \quad \text { 比エンタルピ }[\mathrm{kJ} / \mathrm{kg}] \\
& K \quad \text { ： 熱通過率 }\left[\mathrm{kW} /\left(\mathrm{m}^{2} \cdot \mathrm{K}\right)\right] \\
& N \text { : 吸収器段数 [-] } \\
& P \text { : 圧力 }[\mathrm{kPa}] \\
& Q \quad \text { ： 移動熱量 }[\mathrm{kW}] \\
& T \quad \text { : 温度 }\left[{ }^{\circ} \mathrm{C}\right] \\
& W \quad \text { ：質量流量 }[\mathrm{kg} / \mathrm{s}] \\
& X \quad \text { : 濃度 [wt } \% \text { ] } \\
& \Delta T \quad \text { : 温度差 }\left[{ }^{\circ} \mathrm{C}\right] \\
& \Delta T_{l m} \text { ： 対数平均温度差 }\left[{ }^{\circ} \mathrm{C}\right] \\
& \Delta T_{\min } \text { ： 最小温度差 }\left[{ }^{\circ} \mathrm{C}\right] \\
& \gamma \quad \text { ： 溶液循環比 }[-] \\
& \phi \quad \text { : 温度効率 }[-]
\end{aligned}
$$

\section{添字}

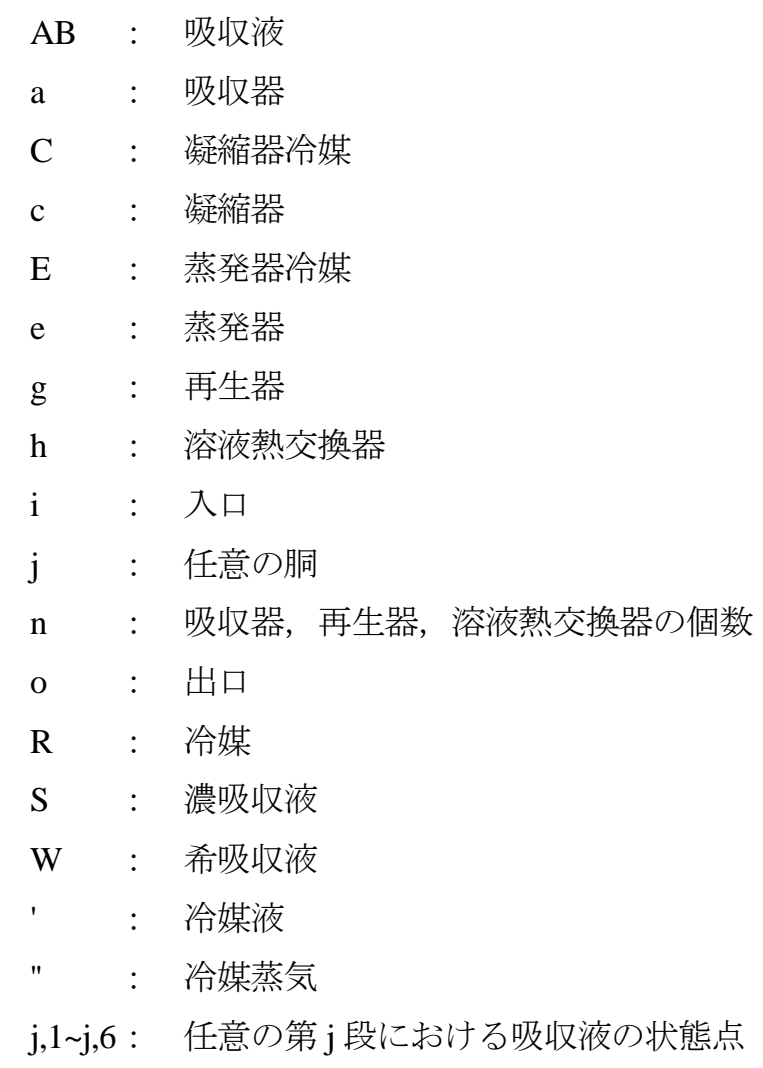




\section{2. 多段吸収を用いた低温水吸収冷凍機のサイクル}

図 1 は蒸発器 $(\mathrm{EVA})$, 凝縮器 $(\mathrm{CON}), \mathrm{n}$ 個の吸収器 $(\mathrm{ABS} 1, \mathrm{ABS} 2 \ldots, \mathrm{ABSn}), \mathrm{n}$ 個の再生器 (GEN1, GEN2..., GENn）および $\mathrm{n}$ 個の溶液熱交換器（HEX1，HEX2..., HEXn）で構成される多段吸収を用いた低温水吸収冷凍機 における冷水，冷却水，温水，冷媒および吸収液の流れを模式的に示したものである. 多段吸収低温水吸収冷凍 機は図 1 の下側からもっとも圧力が低い蒸発器(EVA) と吸収器 1 (ABS1)の要素を組み合わせた第 1 胴, 再生器 1 (GEN1) と吸収器 2 (ABS2)を組み合わせた 2 段吸収の第 2 胴と続き, もっとも圧力が高い最上段の再生器 $\mathrm{n}(\mathrm{GENn})$ と凝縮器 $(\mathrm{CON})$ を組み合わせた第 $\mathrm{n}+1$ 胴から構成される.

冷水はEVA に流されるが，冷却水および熱源となる温水を流す方法については種々考えられる. 冷却水は一般 的に吸収器に導入されたのち，凝縮器に供給される場合が多いが，本報告ではシミュレーションがより簡便であ ることおよび吸収器が多段であることによって結果に大きな違いが生じないことから, 冷却水は CON も含めて $\mathrm{n}$ 個の ABS すべてに並列に導入するほか, 温水もn 個の GENすべてに並列に導入するものとした.

吸收液の流れはABS1 においてEVA で蒸発した冷媒蒸気を吸収した希吸収液 1 は熱交換器 HEX1 で加熱された のち, GEN1 で泠媒を蒸発し濃吸収液 1 となり, HEX1 で泠却されて再びABS1 に戻る. 同様に, 任意の第 $\mathrm{j}$ 胴に おいては，GENj-1 で蒸発した冷媒蒸気を ABSj で吸収した希吸収液 $\mathrm{j}$ は熱交換器 HEXj を通り, GENj で冷媒を 蒸発して濃吸収液 $\mathrm{j}$ となって再び HEXj を通って $\mathrm{ABSj}$ に戻る. 寸なわち, $\mathrm{ABSj}$ と GENj の間を循環する吸收液 はその前後の胴を循環している吸収液と混合されることはない.

したがって, EVA から ABS1 への冷媒蒸気の流量 $W_{\mathrm{R}}$ は任意の第 $\mathrm{j}$ 胴において GENj-1 から ABSj 移動する冷 媒蒸気流量と同じ $W_{\mathrm{R}}$ でなければならない. 最上部の第 $\mathrm{n}+1$ 胴においても同様であり, GENn から蒸発して CON で凝縮する冷媒流量は $W_{\mathrm{R}}$ に等しく, その凝縮冷媒が低圧胴の EVA で蒸発することになる.

図 2 は臭化リチウム水溶液のデューリング線図上に本研究において対象としている多段吸収を用いた低温水吸 収冷凍機のサイクルを示したものであり, 図 2 中の第 $\mathrm{j}$ 胴における $1, \mathrm{j} \sim 6, \mathrm{j}$ 等の添字番号は図 1 中に示した第 $\mathrm{j}$ 胴 における吸収液温度の添字番号に対応している.

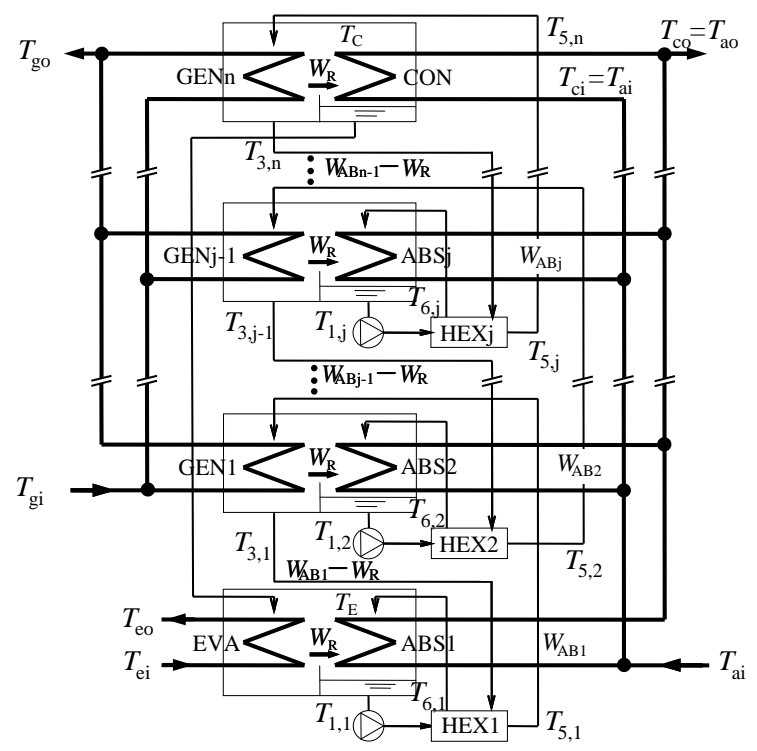

Fig. 1 Schematic diagram of multi-stage absorption refrigerating cycle

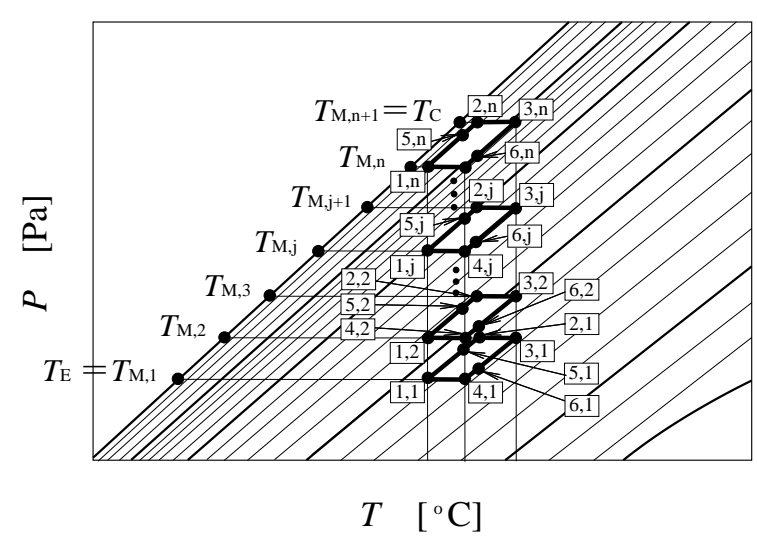

Fig. 2 Dühring diagram of multi-stage absorption refrigerating cycle 


\section{3. 物 質 収 支}

多段吸収を行う低温水吸収冷凍機においては，第 2 章で述べたように図 1 の各胴内を移動する冷媒蒸気流量は すべて同じ $W_{\mathrm{R}}$ である.また，第 $\mathrm{j}$ 胴の $\mathrm{ABSj}$ と第 $\mathrm{j}+1$ 胴の $\mathrm{GENj}$ との間を循環する吸収液は前後の胴を循環して いる吸収液と混合されることがないため, $\mathrm{ABSj}$ に流入する濃吸収液の濃度を $X_{\mathrm{Sj}}$ とし, 冷媒蒸気を吸収して $\mathrm{ABSj}$ を流出する希吸収液の濃度を $X_{\mathrm{Wj}}$ とすると, 吸収液内に存在する臭化リチウムの質量は出入口で同じである.し たがって, 希吸収液の流量を $W_{\mathrm{ABj}}$, 冷媒の流量を $W_{\mathrm{R}}$ とすると臭化りチウムの物質収支から次式が成立する.

$$
W_{\mathrm{ABj}} X_{\mathrm{Wj}}=\left(W_{\mathrm{ABj}}-W_{\mathrm{R}}\right) X_{\mathrm{Sj}}
$$

ここで, $\gamma_{\mathrm{j}}\left(=W_{\mathrm{AB}} / W_{\mathrm{R}}\right)$ を冷媒蒸気単位質量あたりの吸収液 $\mathrm{j}$ の溶液循環比と定義すると次式の関係が得られる.

$$
\begin{aligned}
& \gamma_{\mathrm{j}} X_{\mathrm{wj}_{\mathrm{j}}}=\left(\gamma_{\mathrm{j}}-1\right) X_{\mathrm{Sj}} \\
& \gamma_{\mathrm{j}}=\frac{X_{\mathrm{Sj}}}{X_{\mathrm{Sj}}-X_{\mathrm{wj}_{\mathrm{j}}}}
\end{aligned}
$$

\section{4. 熱 収 支}

\section{$4 \cdot 1$ 総括熱収支}

図 1 に示した蒸発器，1〜nの吸収器，1～n の再生器および疑縮器において交換される熱量がそれぞれ $Q_{\mathrm{e}}, Q_{\mathrm{a} 1}$ $\sim Q_{\mathrm{an}}, Q_{\mathrm{g} 1} \sim Q_{\mathrm{gn}}$ および $Q_{\mathrm{c}}$ であるとすると, 熱損失を無視した場合, 総括熱収支である式(4)が成立しなければな らない.

$$
Q_{\mathrm{e}}+\sum_{\mathrm{j}=1}^{\mathrm{n}} Q_{\mathrm{gj}}=\sum_{\mathrm{j}=1}^{\mathrm{n}} Q_{\mathrm{aj}}+Q_{\mathrm{c}}
$$

\section{$4 \cdot 2$ 各要素における熱収支}

\section{$4 \cdot 2 \cdot 1$ 蒸発器 (EVA)}

伝熱管内を流れる冷水の入口および出口温度をそれぞれ $T_{\mathrm{ei}}$ および $T_{\mathrm{e} o}$ とし，泠水流量を $W_{\mathrm{e}}$ ，泠水の定圧比熱 を $c_{P \mathrm{e}}$ とすると, 蒸発器における冷熱量 $Q_{\mathrm{e}}$ は次式(5)で表される.

$$
Q_{\mathrm{e}}=c_{P \mathrm{e}} W_{\mathrm{e}}\left(T_{\mathrm{ei}}-T_{\mathrm{eo}}\right)
$$

一方, 伝熱管外側で蒸発する冷媒の蒸発量を $W_{\mathrm{R}}$, 凝縮器から蒸発器に入ってくる冷媒液の比エンタルピを $h_{\mathrm{C}}$ および蒸発器で蒸発する冷媒蒸気の比エンタルピを $h_{\mathrm{E}} "$ とすると蒸発器において冷媒が蒸発することによって失 われる熱量は式(6)で表される.

$$
Q_{\mathrm{e}}=W_{\mathrm{R}}\left(h_{\mathrm{E}}{ }^{\prime \prime}-h_{\mathrm{C}}{ }^{\prime}\right)
$$

これらの熱量は蒸発器だけでなく, 後述するその他の要素においても同様であるが, 向流熱交換器として蒸発 器の熱通過率 $K_{\mathrm{e}}$, 伝熱面積 $A_{\mathrm{e}}$ および図 2 の蒸発圧力 $P_{\mathrm{E}}$ における飽和温度 $T_{\mathrm{E}}$ と冷水の出入口温度で与えられる対 数平均温度差 $\Delta T_{l m \mathrm{e}}$ を用いて式(7)で与えられる交換熱量とも等しくなければならない.

$$
\begin{aligned}
Q_{\mathrm{e}} & =K_{\mathrm{e}} A_{\mathrm{e}} \Delta T_{l m e} \\
& =K_{\mathrm{e}} A_{\mathrm{e}} \frac{\left(T_{\mathrm{ei}}-T_{\mathrm{E}}\right)-\left(T_{\mathrm{eo}}-T_{\mathrm{E}}\right)}{\ln \left\{\left(T_{\mathrm{ei}}-T_{\mathrm{E}}\right) /\left(T_{\mathrm{eo}}-T_{\mathrm{E}}\right)\right\}}
\end{aligned}
$$




\section{$4 \cdot 2 \cdot 2$ 第 $\mathrm{j}$ 胴の吸収器 $\mathrm{j}(\mathrm{ABSj})$}

$\mathrm{ABSj}$ に導入される冷却水の入口および出口温度をそれぞれ $T_{\mathrm{ai}}$ および $T_{\mathrm{a}}$, 冷却水流量を $W_{\mathrm{aj}}$, 冷却水の定圧比 熱を $c_{P \mathrm{a}}$ とすると, $\mathrm{ABSj}$ における冷却熱量 $Q_{\mathrm{aj}}$ は次式(8)で表される.

$$
Q_{\mathrm{aj}}=c_{P_{\mathrm{a}}} W_{\mathrm{aj}}\left(T_{\mathrm{ao}}-T_{\mathrm{ai}}\right)
$$

また，希吸収液流量を $W_{\mathrm{ABj}}, \quad \mathrm{GENj}-1$ から $\mathrm{ABSj}$ 一移動する冷媒蒸気の流量を $W_{\mathrm{R}}$ ，第 $\mathrm{j}+1$ 胴の $\mathrm{GENj}$ から溶 液熱交換器（HEXj）を通過して $\mathrm{ABSj}$ に入ってくる濃吸収液の比エンタルピを $h_{6, \mathrm{j}}, \mathrm{ABSj}$ を出て行く希吸収液の 比エンタルピを $h_{1, \mathrm{j}}$ とすると, 冷却水に放出する熱量は溶液循環比 $\gamma_{\mathrm{j}}$ を用いて式(9)で表される.

$$
\begin{aligned}
Q_{\mathrm{aj}} & =\left(W_{\mathrm{ABj}}-W_{\mathrm{R}}\right) h_{6, \mathrm{j}}+W_{\mathrm{R}} h_{3, \mathrm{j}-1} "-W_{\mathrm{ABj}} h_{1, \mathrm{j}} \\
& =\left(\gamma_{\mathrm{j}}-1\right) W_{\mathrm{R}} h_{6, \mathrm{j}}+W_{\mathrm{R}} h_{3, \mathrm{j}-1}{ }^{\prime}-\gamma_{\mathrm{j}} W_{\mathrm{R}} h_{1, \mathrm{j}}
\end{aligned}
$$

さらに, この交換熱量は $\mathrm{ABSj}$ の熱通過率 $K_{\mathrm{aj}}$, 伝熱面積 $A_{\mathrm{aj}}$, 吸収液の入口温度 $T_{4 \mathrm{j}}$ および出口温度 $T_{1, \mathrm{j}}$ と冷却 水の出入口温度で与えられる対数平均温度差 $\Delta T_{l m \mathrm{aj}}$ を用いて式(10)で与えられる熱量と等しくならなければなら ない.

$$
\begin{aligned}
Q_{\mathrm{aj}} & =K_{\mathrm{aj}} A_{\mathrm{aj}} \Delta T_{\text {lmaj }} \\
& =K_{\mathrm{aj}} A_{\mathrm{aj}} \frac{\left(T_{4, \mathrm{j}}-T_{\mathrm{ao}}\right)-\left(T_{1, \mathrm{j}}-T_{\mathrm{ai}}\right)}{\ln \left\{\left(T_{4, \mathrm{j}}-T_{\mathrm{ao}}\right) /\left(T_{1, \mathrm{j}}-T_{\mathrm{ai}}\right)\right\}}
\end{aligned}
$$

ここで, GENj から HEXj を通過して ABSj に入ってくる吸収液の温度は $T_{6, j}$ であるが, 図 2 のデューリング線図 上における $T_{4, \mathrm{j}}$ が設計においては通常用いられている.

\section{$4 \cdot 2 \cdot 3$ 凝縮器 $(\mathrm{CON})$}

$\mathrm{CON}$ の伝熱管内を流れる冷却水の入口および出口温度をそれぞれ $T_{\mathrm{ci}}$ および $T_{\mathrm{co}}$, 冷却水流量を $W_{\mathrm{c}}$, 冷却水の 定圧比熱を $c_{P_{\mathrm{c}}}$ とすると, CONにおける凝縮熱量 $Q_{\mathrm{c}}$ は次式(11)で表わすことができる.

$$
Q_{\mathrm{c}}=c_{P_{C}} W_{\mathrm{c}}\left(T_{\mathrm{co}}-T_{\mathrm{ci}}\right)
$$

一方，管外において凝縮する冷媒流量は $W_{\mathrm{R}}$ であるから，GENn から発生する過熱冷媒蒸気の比エンタルピを $h_{3, n, n}{ }^{\prime}$ 凝縮した飽和水の比エンタルピを $h^{\prime}$ とすると冷媒の凝縮熱量 $Q_{\mathrm{c}}$ は次式(12)で表される.

$$
Q_{\mathrm{c}}=W_{\mathrm{R}}\left(h_{3, \mathrm{n}}{ }^{\prime \prime}-h_{\mathrm{C}}{ }^{\prime}\right)
$$

この交換熱量 $Q_{\mathrm{c}}$ は $\mathrm{CON}$ の熱通過率 $K_{\mathrm{c}}$, 伝熱面積 $A_{\mathrm{c}}, \mathrm{CON}$ における飽和温度 $T_{\mathrm{C}}$ と冷却水の出入口温度で与え られる対数平均温度差 $\Delta T_{l m c}$ を用いた式(13)で与えられる熱量と等しい.

$$
\begin{aligned}
Q_{\mathrm{c}} & =K_{\mathrm{c}} A_{\mathrm{c}} \Delta T_{l m \mathrm{c}} \\
& =K_{\mathrm{c}} A_{\mathrm{c}} \frac{\left(T_{\mathrm{C}}-T_{\mathrm{ci}}\right)-\left(T_{\mathrm{C}}-T_{\mathrm{co}}\right)}{\ln \left\{\left(T_{\mathrm{C}}-T_{\mathrm{ci}}\right) /\left(T_{\mathrm{C}}-T_{\mathrm{co}}\right)\right\}}
\end{aligned}
$$




\section{$4 \cdot 2 \cdot 4$ 第 $\mathrm{j}+1$ 胴の再生器 $\mathrm{j}(\mathrm{GENj})$}

GENj の伝熱管内を流れる温水の入口および出口温度をそれぞれ $T_{\mathrm{gi}}$ および $T_{\mathrm{g} 0}$, 温水流量を $W_{\mathrm{gg}}$, 温水の定圧比 熱を $c_{P \mathrm{~g}}$ とすると, 再生器における温水による加熱量 $Q_{\mathrm{g}}$ は次式(14)で表わされる.

$$
Q_{\mathrm{gj}}=c_{P \mathrm{~g}} W_{\mathrm{gj}}\left(T_{\mathrm{gi}}-T_{\mathrm{go}}\right)
$$

管外においては，温水から受熱して GENj から蒸発する過熱冷媒蒸気の比エンタルピと流出する濃吸収液の比 エンタルピをそれぞれ $h_{3, \mathrm{j}}{ }^{\prime}$ および $h_{3, \mathrm{j}}$ とし，HEXj を通過して GENj に入ってくる希吸收液の比エンタルピを $h_{5, \mathrm{j}}$ とすると, GENj における受熱量 $Q_{\mathrm{g}}$ は式(15)で表される.

$$
\begin{aligned}
Q_{\mathrm{gj}} & =\left(W_{\mathrm{ABj}}-W_{\mathrm{R}}\right) h_{3, \mathrm{j}}+W_{\mathrm{R}} h_{3, \mathrm{j}} "-W_{\mathrm{ABj}} h_{5, \mathrm{j}} \\
& =\left(\gamma_{\mathrm{j}}-1\right) W_{\mathrm{R}} h_{3, \mathrm{j}}+W_{\mathrm{R}} h_{3, \mathrm{j}} "-\gamma_{\mathrm{j}} W_{\mathrm{R}} h_{5, \mathrm{j}}
\end{aligned}
$$

さらに, この交換熱量は GENj の熱通過率 $K_{\mathrm{gj}}$, 伝熱面積 $A_{\mathrm{g} j}$, 希吸収液の入口温度 $T_{2, \mathrm{j}}$ および濃吸収液の出口温 度 $T_{3, \mathrm{j}}$ と温水の入口温度 $T_{\mathrm{gi}}$ と出口温度 $T_{\mathrm{g} 0}$ から与えられる対数平均温度差 $\Delta T_{l m \mathrm{~g}}$ を用いて式(16)で与えられる熱量 と等しくならなければならない。

$$
\begin{aligned}
Q_{\mathrm{gj}} & =K_{\mathrm{gj}} A_{\mathrm{gj}} \Delta T_{l m \mathrm{gj}} \\
& =K_{\mathrm{gj}} A_{\mathrm{gj}} \frac{\left(T_{\mathrm{gi}}-T_{3, \mathrm{j}}\right)-\left(T_{\mathrm{go}}-T_{2, \mathrm{j}}\right)}{\ln \left\{\left(T_{\mathrm{gi}}-T_{3, \mathrm{j}}\right) /\left(T_{\mathrm{go}}-T_{2, \mathrm{j}}\right)\right\}}
\end{aligned}
$$

ここでも，対数平均温度差に用いる再生器入口の温度は $T_{5, \mathrm{j}}$ ではなく $T_{2, \mathrm{j}}$ の值を設計上用いている.

\section{$4 \cdot 2 \cdot 5$ 溶液熱交換器 $\mathrm{j}(\mathrm{HEXj})$}

HEXj で交換される熱量 $Q_{\mathrm{hj}}$ は式(17)で表される希吸収液側の受熱量と式(18)で表される濃吸収液側の放熱量が 等しくなければならない，また，これらの交換熱量は式(19)で定義される希吸収液および濃吸収液それぞれの出 入口温度から算出される対数平均温度差 $\Delta T_{l \mathrm{mhj}}$ を用いて与えられる交換熱量とも等しくなければならない。

$$
\begin{aligned}
Q_{\mathrm{hj}} & =W_{\mathrm{ABj}}\left(h_{5, \mathrm{j}}-h_{\mathrm{l}, \mathrm{j}}\right) \\
& =\gamma_{\mathrm{j}} W_{\mathrm{R}}\left(h_{5, \mathrm{j}}-h_{1, \mathrm{j}}\right) \\
Q_{\mathrm{hj}} & =\left(W_{\mathrm{ABj}}-W_{\mathrm{R}}\right)\left(h_{3, \mathrm{j}}-h_{6, \mathrm{j}}\right) \\
& =\left(\gamma_{\mathrm{j}}-1\right) W_{\mathrm{R}}\left(h_{3, \mathrm{j}}-h_{6, \mathrm{j}}\right) \\
Q_{\mathrm{hj}} & =K_{\mathrm{hj}} A_{\mathrm{hj}} \Delta T_{l m \mathrm{hj}} \\
& =K_{\mathrm{hj}} A_{\mathrm{hj}} \frac{\left(T_{3, \mathrm{j}}-T_{5, \mathrm{j}}\right)-\left(T_{6, \mathrm{j}}-T_{1, \mathrm{j}}\right)}{\ln \left\{\left(T_{3, \mathrm{j}}-T_{5, \mathrm{j}}\right) /\left(T_{6, \mathrm{j}}-T_{1, \mathrm{j}}\right)\right\}}
\end{aligned}
$$

\section{$4 \cdot 3$ 溶液熱交換器における温度効率 $\phi$ の定義}

温度効率は濃吸収液側のほうが希吸収液側の温度効率より大きくなることから, 濃吸収液側の温度差を用いて 第 $\mathrm{j}$ 番目の HEXj に対して，次式のように $\phi_{\mathrm{j}}$ で定義する．(江崎他, 2011a p.154)

$$
\phi_{\mathrm{j}}=\frac{T_{3, \mathrm{j}}-T_{6, \mathrm{j}}}{T_{3, \mathrm{j}}-T_{1, \mathrm{j}}}
$$




\section{$4 \cdot 4$ COPの定義}

多段吸収低温水吸収冷凍機の $C O P$ は次式のように $\mathrm{n}$ 個の再生器からの入熱量 $Q_{\mathrm{g} 1} \sim Q_{\mathrm{gn}}$ の合計熱量に対する蒸 発器における冷熱量 $Q_{\mathrm{e}}$ の比と定義する.

$$
C O P=\frac{Q_{\mathrm{e}}}{\sum_{\mathrm{j}=1}^{\mathrm{n}} Q_{\mathrm{gj}}}
$$

\section{5. シミュレーション}

\section{$5 \cdot 1$ シミュレーションの前提条件}

(1) 熱損失

すべての熱交換器における熱損失は無視するものとする.

(2) 吸収液の状態

吸収冷凍機内部を循環する吸収液の温度は定常状態にあり, 圧力および吸収液の濃度と常に平衡状態にあるも のとする.

(3) 冷媒蒸気流が存在する要素間の圧力差

図 1 における第 1 第 $\mathrm{n}+1$ 胴それぞれの胴内において，冷媒蒸気が管群内を移動することによって生じる各要 素間の圧力差は無視できるものとする.

(4) 冷水・冷却水・温水の温度条件

冷水, 冷却水および温水の温度条件を表 1 に示寸. 冷水の入口温度条件は $9 \sim 15^{\circ} \mathrm{C}$ 範囲, 冷却水の入口温度

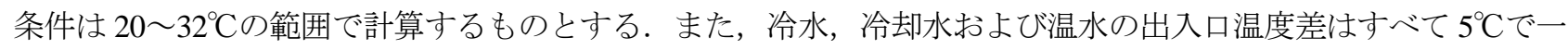
定として計算を行った。限界温水入口温度はこれらの温度条件下において，シミュレーションによって得られる 温水入口温度であり，空調に利用可能な温水の限界最低温度である.

(5) 対数平均に用いる最小温度差の条件

本研究で行うミュレーションにおいては，利用可能な熱源である温水の最低温度を求めるような限界設計を行 う場合には，それぞれの要素における対数平均温度差を定義する二つの温度差のうち，小さくなる側の温度差を 設計上可能な最小温度差として先に設定したほうが効果的であることに着目し，この最小温度差を固定して計算 する新しい方法をすでに提案 (江崎他, 2011a), (江崎他, 2011b) している. すなわち，本報告で取り扱う表 1 の計 算条件では，各要素の最小温度差はそれぞれ EVAにおいては式(7)中の $\left(T_{\mathrm{eo}}-T_{\mathrm{E}}\right)$, 第 $\mathrm{j}$ 番目の $\mathrm{ABSj}$ においては式 (10)の $\left(T_{1, j}-T_{\mathrm{ai}}\right), C O N$ においては式(13)中の $\left(T_{\mathrm{C}}-T_{\mathrm{co}}\right)$, 第 $\mathrm{j}$ 番目の $\mathrm{GENj}$ においては式(16)中の $\left(T_{\mathrm{gi}}-T_{3, \mathrm{j}}\right)$ である. 表 2 にそれらの設定值をまとめて示しているが，これらの值は著者らがこれまで永年にわたって多種多彩な吸収 冷凍機あるいは吸収ヒートポンプの設計製造に携わった経験から実現可能な值として設定したものである.

Table 1 Calculating conditions of multi-stage absorption refrigerating cycle

\begin{tabular}{|c|c|c|c|}
\hline Item & $\begin{array}{c}\text { Temperature differences } \\
{\left[{ }^{\circ} \mathrm{C}\right]}\end{array}$ & $\begin{array}{c}\text { Inlet temperature range } \\
{\left[{ }^{\circ} \mathrm{C}\right]}\end{array}$ & $\begin{array}{c}\text { Outlet temperature range } \\
{\left[{ }^{\circ} \mathrm{C}\right]}\end{array}$ \\
\hline \hline Chilled water & 5 & $9 \sim 15$ & $4 \sim 10$ \\
\hline Cooling water & 5 & $20 \sim 32$ & $23 \sim 37$ \\
\hline Hot water & 5 & Minimum temperature & Minimum temperature \\
\hline
\end{tabular}


Table 2 Minimum temperature differences used the logarithmic mean temperature difference

\begin{tabular}{|c|c|}
\hline Element & Minimum temperature differences $\left[{ }^{\circ} \mathrm{C}\right]$ \\
\hline \hline EVA & 0.5 \\
\hline ABS1 $\sim \mathrm{ABSn}$ & 2.0 \\
\hline $\mathrm{CON}$ & 1.0 \\
\hline $\mathrm{GEN} 1 \sim \mathrm{GENn}$ & 3.0 \\
\hline
\end{tabular}

\section{（6）溶液熱交換器の温度効率}

溶液熱交換器 HEX1〜HEXn の温度効率はすべて実用的な值である 90\%として計算することにした.

なお，臭化リチウムー水系の圧力，温度，濃度およびエンタルピの関係は文献 (Mcneely, 1979) の值を用いて 計算した.

\section{$5 \cdot 2$ 単効用低温水吸収冷凍機のシミュレーション結果}

前述した最小温度差の考え方を用いた単効用低温水吸収冷凍機のシミュレーション手法およびその結果につい ては既報 (江崎他, 2011a) で報告しているが，以下に冷却水を ABS と CON に並列供給した場合における単効用 低温水吸収冷凍機の計算結果について説明しておく. 図 3 は冷水, 冷却水および温水の出入口温度差がすべて $5^{\circ} \mathrm{C}$ であり，冷水入口温度が $14^{\circ} \mathrm{C}$, 冷却水入口温度が $29^{\circ} \mathrm{C}$ 条件下において, 冷凍能力 $1 \mathrm{~kW}$ あたりの希吸収液流量 $W_{\mathrm{AB}}$ に対する温水入口温度の計算結果である. 図 3 から $W_{\mathrm{AB}}$ を変化させると温水入口温度はしだいに減少するが, ある領域で一定の最低温度を示したのちに上昇する傾向にあるのがわかる。このシミュレーション例の場合, $W_{\mathrm{AB}}$

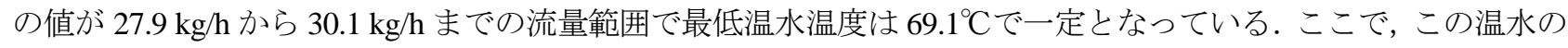
最低温度領域を与える $W_{\mathrm{AB}}$ の值が小さい $27.9 \mathrm{~kg} / \mathrm{h}$ における条件は吸収器における二つの温度差 $\left(T_{1}-T_{\mathrm{ai}}\right)$ および $\left(T_{4}\right.$ $\left.-T_{\mathrm{ao}}\right)$ が同じ最小温度差となる場合である. すなわち, 吸収液の出入口温度差 $\left(T_{4}-T_{1}\right)$ と冷却水の出入口温度差 $\left(T_{\mathrm{a}}\right.$ 一 $\left.T_{\mathrm{ai}}\right)$ が同じ值となる場合である。一方， $W_{\mathrm{AB}}$ の值が大きいほうである $30.1[\mathrm{~kg} / \mathrm{h}]$ の場合の条件は再生器において 最小温度差として設定した $\left(T_{\mathrm{go}}-T_{2}\right)$ の值ともう一方の温度差 $\left(T_{\mathrm{gi}}-T_{3}\right)$ の值が同じ最小温度差となる場合, すなわ ち再生器における吸収液の出入口温度差 $\left(T_{3}-T_{2}\right)$ と温水の出入口温度差 $\left(T_{\mathrm{gi}}-T_{\mathrm{go}}\right)$ が同じ值となる場合である.

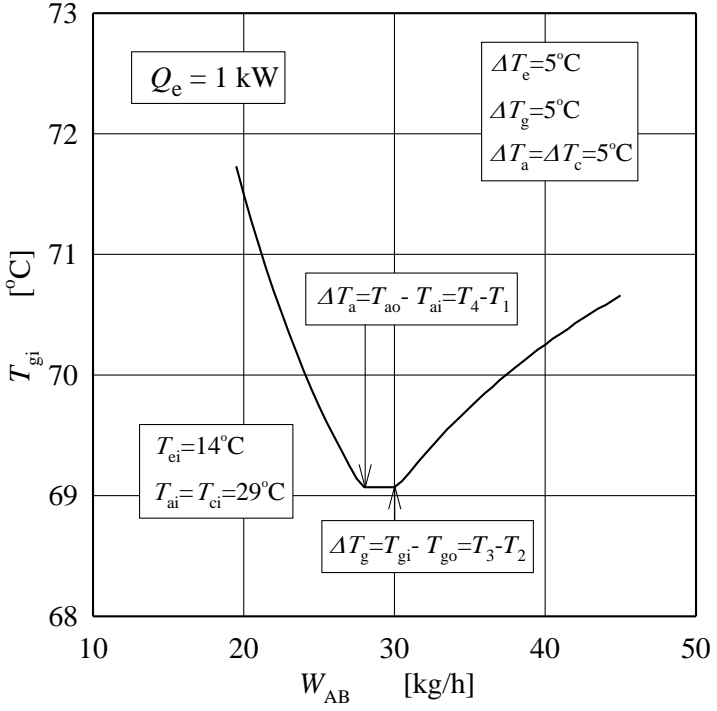

Fig. 3 Effect of weak solution flow rate on the inlet temperature of hot water

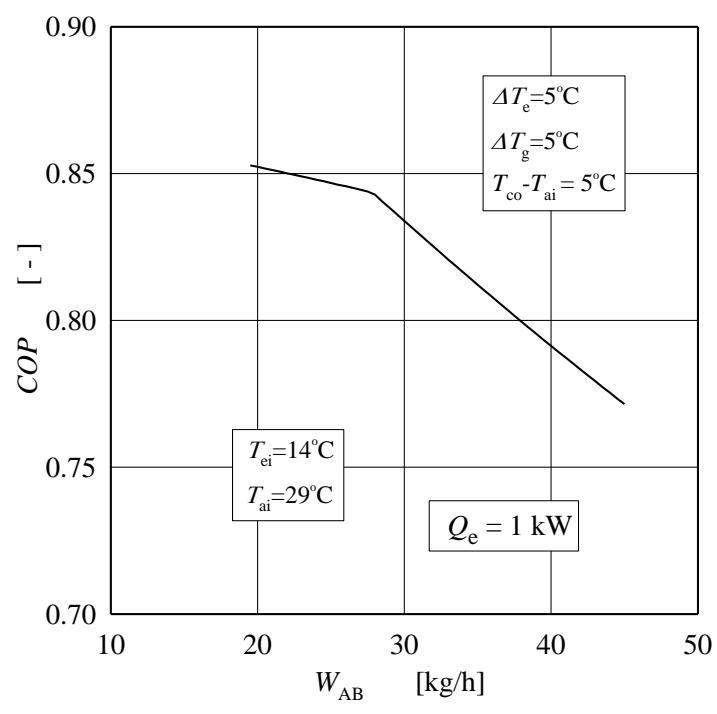

Fig. 4 Effect of weak solution flow rate on $C O P$ 
Esaki, Kobayashi, Ohnou and Kaneko, Transactions of the JSME (in Japanese), Vol.80, No.814 (2014)

図 4 は図 3 と同じ条件下で計算した $W_{\mathrm{AB}}$ に対する $C O P$ との関係を示したものである. 図 4 から $W_{\mathrm{AB}}$ を増加さ せた場合 $C O P$ はしだいに減少しているのがわかる. 図3で示したように温水が一定で同じ最低温度を示すなら ば, $C O P$ が大きい方を選択すべきであるから, 温水温度が最低の温度を与える条件は吸収器における吸収液の出 入口温度差 $\left(T_{4}-T_{1}\right)$ と冷却水の出入口温度差 $\left(T_{\mathrm{ao}}-T_{\mathrm{ai}}=\Delta T_{\mathrm{a}}\right)$ が同じ温度差になる場合であることがわかる. な お，シミュレーションの前提条件となる表 1 で設定した温度および温度差を他の值に変えて同様のシミュレーシ ヨンを行った結果，上記の関係はいずれの条件の場合でも同様の特性を持つことが確認されたことから，本研究 における多段吸収を用いたシミュレーションに対してもこの関係を導入することにする.

\section{$5 \cdot 3$ 多段吸収のシミュレーション手順}

多段吸収を用いた低温水吸收冷凍機の温水入口限界温度を求めるシミュレーションのアルゴリズムについて以 下に説明する。

(1) 表 1 で設定した冷水の出口温度 $T_{\mathrm{eo}}$ と表 2 で定めた EVA における最小温度差 $\Delta T_{\text {mine }}\left(=T_{\mathrm{eo}}-T_{\mathrm{E}}\right)$ から, 蒸発温度 $T_{\mathrm{E}}$ すなわち第 1 胴の飽和温度である $T_{\mathrm{M}, 1}$ を計算して冷媒の蒸発圧力 $P_{\mathrm{E}}$ を与える.

(2) 同じように, 表 1 で設定した冷却水の出口温度 $T_{\mathrm{co}}$ と表 2 で定めた CON における最小温度差 $\Delta T_{\operatorname{minc}}\left(=T_{\mathrm{C}}-T_{\mathrm{co}}\right)$ から，凝縮温度 $T_{\mathrm{C}}$ を計算して冷媒の凝縮圧力 $P_{\mathrm{C}}$ を与える。

（3）表 1 で設定した冷却水の入口温度 $T_{\mathrm{ai}}$ と表 2 で定めた ABS1 における最小温度差 $\Delta T_{\text {mina }}\left(=T_{1,1}-T_{\mathrm{ai}}\right)$ から, 吸収 液出口温度 $T_{1,1}$ を計算する.

(4) 図 2 のデューリング線図上で明らかなように， $P_{\mathrm{E}}$ および $T_{1,1}$ から希吸収液濃度 $X_{\mathrm{W}_{1}}$ が決定される.

(5) ここで, $C O P$ が最大で最低の温水温度が得られる条件となる吸収器の吸収液出入口温度差 $\left(T_{4,1}-T_{1,1}\right)$ と冷却 水出入口温度差 $\Delta T_{\mathrm{a}}\left(=T_{\mathrm{ao}}-T_{\mathrm{ai}}\right.$ 名等しくなる関係を用いる. 寸なわち， $T_{1,1}$ と $\Delta T_{\mathrm{a}}$ から $T_{4.1}$ を算出し， $P_{\mathrm{E}}$ およ び $T_{4,1}$ から濃吸収液濃度 $X_{\mathrm{S} 1}$ を決定する。

(6) $n$ 段吸収の場合, まず第 2 胴の飽和温度 $T_{\mathrm{M}, 2}$ を第 1 次近似值として $T_{\mathrm{C}}$ と $T_{\mathrm{E}}$ の差を $n$ 等分し, $T_{\mathrm{M}, 2}=\left(T_{\mathrm{C}}-T_{\mathrm{E}}\right) / n$ $+T_{\mathrm{E}}$ で計算して飽和圧力 $P_{\mathrm{M}, 2}$ を与える.

(7) $P_{\mathrm{M}, 2}$ および $X_{\mathrm{S} 1}$ から $T_{3,1}$ を算出する. ここで, $n$ 個の吸収器に並列に導入する冷却水の温度条件がすべて同じ であるため，上記(3)の過程における計算はすすへての吸収器で適用されることから， $T_{1,1}=T_{1,2}=\ldots=T_{1, \mathrm{n}}$ であり， 上記(5)の過程から $T_{4,1}=T_{4,2}=\ldots=T_{4, \mathrm{n}}$ となる. また, $n$ 個の再生器に並列に導入される温水の出入口温度条件も すべて同じであるほか，表 1 で設定したすべての GEN における最小温度差 $\Delta T_{m i n g}\left(=T_{\mathrm{gi}}-T_{3 \mathrm{j}}\right)$ も同じと設定し ているため, $T_{3,1}=T_{3,2}=\ldots=T_{3, \mathrm{n}}$ とならなければならない.

（8）上記(6)で仮定した $P_{\mathrm{M}, 2}$ および $T_{4,2}$ から濃吸収液濃度 $X_{\mathrm{S} 2}$ を決定し，この $X_{\mathrm{S} 2}$ とすでに決定されている $T_{3,2}$ から 次段の飽和圧力 $P_{\mathrm{M}, 3}$ を与える. 同様の方法で順次計算を行い, $X_{\mathrm{Sn}}$ と $T_{3, \mathrm{n}}$ から最終段の飽和圧力 $P_{\mathrm{M}, \mathrm{n}+1}$ を計算 し, この圧力における水蒸気の飽和温度 $T_{\mathrm{M}, \mathrm{n}+1}$ を算出する. ただし, $T_{\mathrm{M}, \mathrm{n}+1}=T_{\mathrm{C}}$ でなければならないため, 第 1 近似の $T_{\mathrm{M}, 2}$ に $\left(T_{\mathrm{C}}-T_{\mathrm{M}, \mathrm{n}}\right) / \mathrm{n}$ を加えた修正を行い， $T_{\mathrm{M}, \mathrm{n}+1}=T_{\mathrm{C}}$ となるまで繰り返し行う.

(9) 前項 $(8)$ で決定された任意の第 $\mathrm{j}$ 胴の圧力 $P_{\mathrm{M}, \mathrm{j}}$ および $T_{1, j}$ から $X_{\mathrm{Wj}}$ が与えられ, 次の第 $\mathrm{j}+1$ 胴の圧力 $P_{\mathrm{M}, \mathrm{j}+1}$ と $X_{\mathrm{Wj}}$ から $T_{2, \mathrm{j}}$ は決定される.

(10) 表 2 において GEN で定義した最小温度差 $\Delta T_{m i n g}\left(=T_{\mathrm{gi}}-T_{3, j}\right)$ から温水の入口温度 $T_{\mathrm{gi}}$ が与えられ, 表 1 で設定し た温水出入口温度差から, 温水出口温度 $T_{\mathrm{g} 0}$ が決定される.

(11) $X_{\mathrm{Wj}}$ および $X_{\mathrm{S} \mathrm{j}}$ が決定できたことから，式(3)からそれぞれの吸収液の溶液循環比 $\gamma_{\mathrm{j}}$ が定められる.また, $P_{\mathrm{E}}$ および $P_{\mathrm{C}}$ は寸でに決定されているため, 式(6)から単位冷凍能力 $Q_{\mathrm{e}}=1 \mathrm{~kW}$ あたりの $W_{\mathrm{R}}$ が与えられ, 式(1)から それぞれの希吸収液流量 $W_{\mathrm{ABj}}$ が決定される.

(12) $T_{1, \mathrm{j}}$ および $T_{3, \mathrm{j}}$ はすでに決定されており, 式(20)で定義される HEXj の温度効率から, 濃吸収液側の出口温度 $T_{6, \mathrm{j}}$ が算出される. 


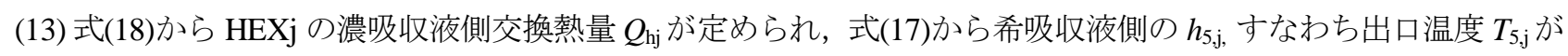
決定される.

(14) 以上で吸収冷凍機内部のサイクルを構成する必要なすべての温度が決定されたことから, 式(9)から $Q_{\mathrm{aj}}$, 式(12) から $Q_{\mathrm{c}}$ ，式(15)から $Q_{\mathrm{gg}}$ がそれぞれ求められる.

(15) 式(5)加冷水流量 $W_{\mathrm{e}}$, 式(8)加各吸収器の冷却水流量 $W_{\mathrm{aj}}$, 式(11)から凝縮器の冷却水流量 $W_{\mathrm{c}}$, 式(14)から 各再生器の温水流量 $W_{\mathrm{gg}}$ が得られ, 式(7), 式(10), 式(13), 式(16) および式(19)から吸収冷凍機の設計計算に 必要な各要素の $K A$ 值が決定される.

\section{$5 \cdot 4$ シミュレーションの結果}

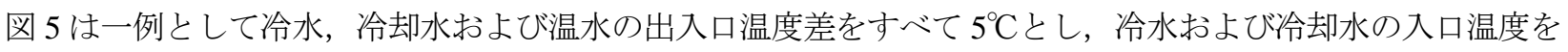
それぞれ $14^{\circ} \mathrm{C}$ よび $29^{\circ} \mathrm{C}$ とた場合における 4 段吸収のシミュレーション結果を示したものである.図 5 中には 各中間胴の圧力, 各 ABS と各 GEN を循環する吸収液の濃度ならびに主要部分における吸収液の平衡温度を示し ている.

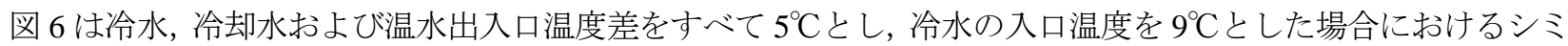
ユレーション結果であり, 冷却水の入口温度をパラメータとして, 横軸に吸収器の段数 $N$ をとり, 縦軸には冷凍 機に投入しなければならない温水の最低入口温度を太線で示したものである. なお，冷水入口温度が温水入口最

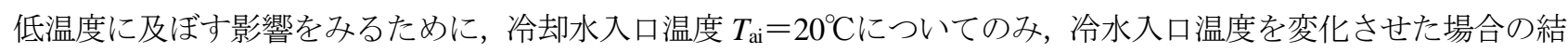
果も細線で示している.

図 6 から，単効用に比べて 2 段吸収では利用できる温水入口温度を $20.4 \sim 12.9^{\circ} \mathrm{C}$ も幅に低下させることが可 能であるほか， 3 段にすればさらに 6.6 4.2 ${ }^{\circ} \mathrm{C}$ 温水温度を低下させることができる. 吸収器の段数 $N$ をさらに増 加寸れば，温水入口温度の低下割合は小さくなるが，温水入口温度をさらに減少できることがわかる．しかし， 図 6 でも示しているように, $T_{\mathrm{ei}}=9^{\circ} \mathrm{C}$ の条件下で泠却水温度が低い $T_{\mathrm{ai}}=20^{\circ} \mathrm{C}$ の場合には 5 段吸収までのみ成立し, それ以上の段数では成立しない. 寸なわち，6段吸収でシミュレーションした場合，図 2 中における $T_{1, \mathrm{n}}=T_{1,6}=$ $22.0^{\circ} \mathrm{C}$ 无の圧力における冷媒の飽和温度 $T_{\mathrm{M}, \mathrm{n}}=T_{\mathrm{M}, 6}=22.1^{\circ} \mathrm{C}$ の值より低くなるため, サイクルが成立しなくなる からである。

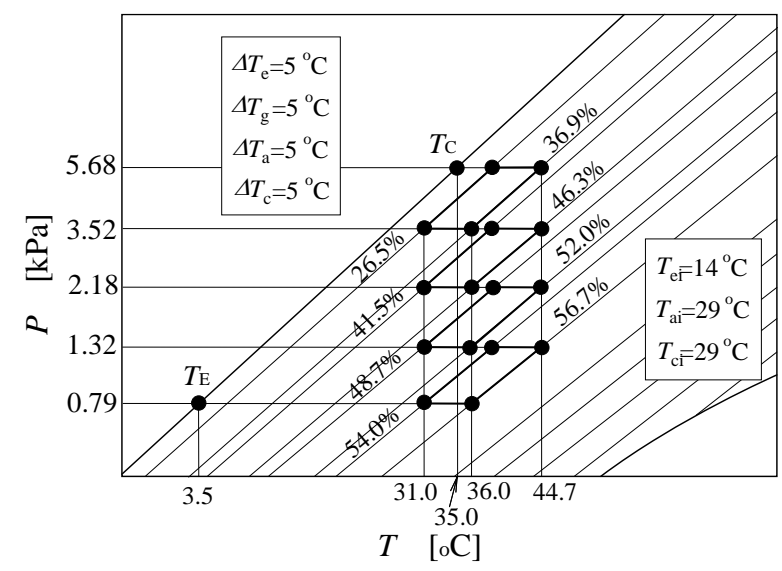

Fig. 5 Example of simulation results

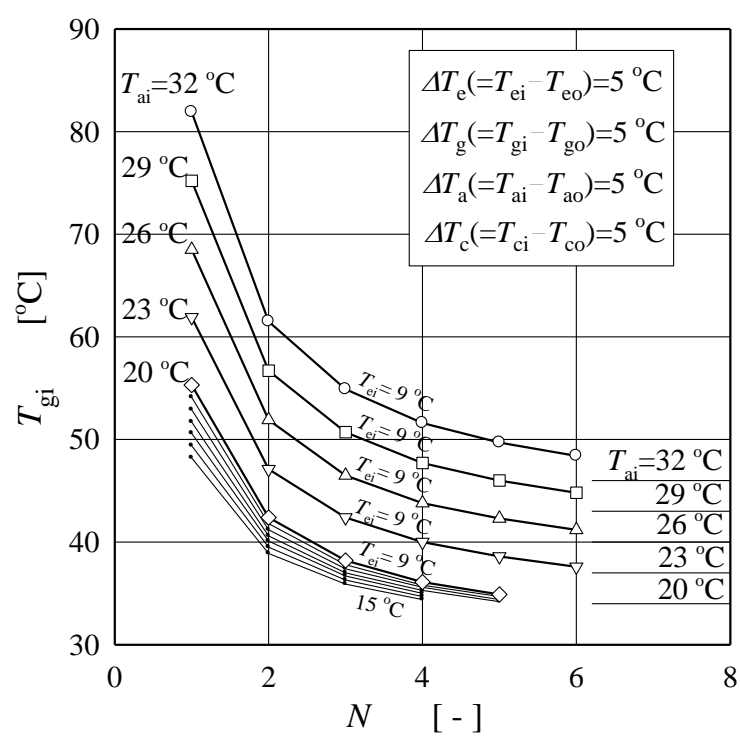

Fig. 6 Characteristics of lower limit temperature for hot water 
理論上の無限段吸収が成立する条件は図 2 において平行四辺形で表される一つのサイクルの上底と下底が接近 して一致する場合である. 寸なわち，任意の第 $\mathrm{j}$ 胴と次の第 $\mathrm{j}+1$ 胴の圧力が等しくなる場合であり，第 $\mathrm{j}$ 胴のサ イクル温度において $T_{1, \mathrm{j}}=T_{2, \mathrm{j}}$ および $T_{3, \mathrm{j}}=T_{4, \mathrm{j}}$ となる場合に相当する. また，前述したように $T_{2, \mathrm{n}}=T_{\mathrm{C}}$ すなわち $T_{1,1}$ $=T_{\mathrm{C}}$ の条件を満足しなければならないことから, 無限段吸収が成立する理論上利用できる最低温水温度は次のよ うに表される。

$5 \cdot 3$ 節の(2)項から

$$
T_{C}=T_{\mathrm{co}}+\Delta T_{\operatorname{minc}}=T_{\mathrm{ci}}+\Delta T_{\mathrm{c}}+\Delta T_{\text {minc }}
$$

であり, $5 \cdot 3$ 節の(5)項から

$$
T_{4,1}=T_{1,1}+\Delta T_{\mathrm{a}}=T_{\mathrm{C}}+\Delta T_{\mathrm{a}}
$$

となる.

また, $5 \cdot 3$ 節の(10)項から

$$
T_{\mathrm{gi}}=T_{3, \mathrm{n}}+\Delta T_{\text {ming }}
$$

であるが, 無限段においては $T_{4,1}=T_{3,1}=T_{3, \mathrm{n}}$ の関係が成立することから, 温水限界最低温度 $T_{\mathrm{gi}}$ は次式で表される.

$$
T_{\mathrm{gi}}=T_{4,1}+\Delta T_{\text {ming }}=T_{\mathrm{C}}+\Delta T_{\mathrm{a}}+\Delta T_{\text {ming }}=T_{\mathrm{ci}}+\Delta T_{\mathrm{c}}+\Delta T_{\text {minc }}+\Delta T_{\mathrm{a}}+\Delta T_{\text {ming }}
$$

図 6 において横軸 $N=6 \sim 8$ の領域に, 上式(25)で計算される各冷却水入口温度 $T_{\mathrm{ai}}$ に対するその限界最低温水温 度を水平な細線で示している，段数には限界があることをすでに説明したが，この温水最低限界温度より低くな る段数は成立しないということである.

図 7 は冷却水入口温度をパラメータとして, 低温水吸収冷凍機の COPに及ぼす吸収段数の影響を示したもの である. 段数 $N$ が増加するに従って, $C O P$ は急激に減少していくのがわかる. また，冷却水入口温度 $T_{\mathrm{ai}}$ を20〜 $32^{\circ} \mathrm{C}$ 変化させた結果も示しているが，ほとんど同じ值を示しており，冷却水温度が $C O P$ に及ぼす影響は小さい ことがわかる. 冷水入口温度の影響については図示していないが, 冷却水温度の影響とほぼ同じ程度であり, $C O P$ に及ぼす影響は小さい。

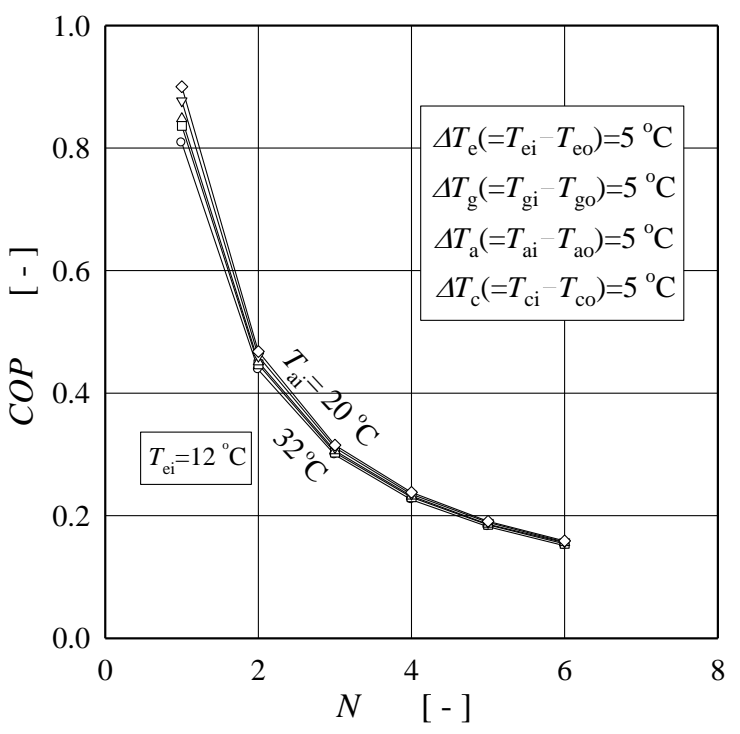

Fig. 7 Characteristics of the $C O P$ 
Esaki, Kobayashi, Ohnou and Kaneko, Transactions of the JSME (in Japanese), Vol.80, No.814 (2014)

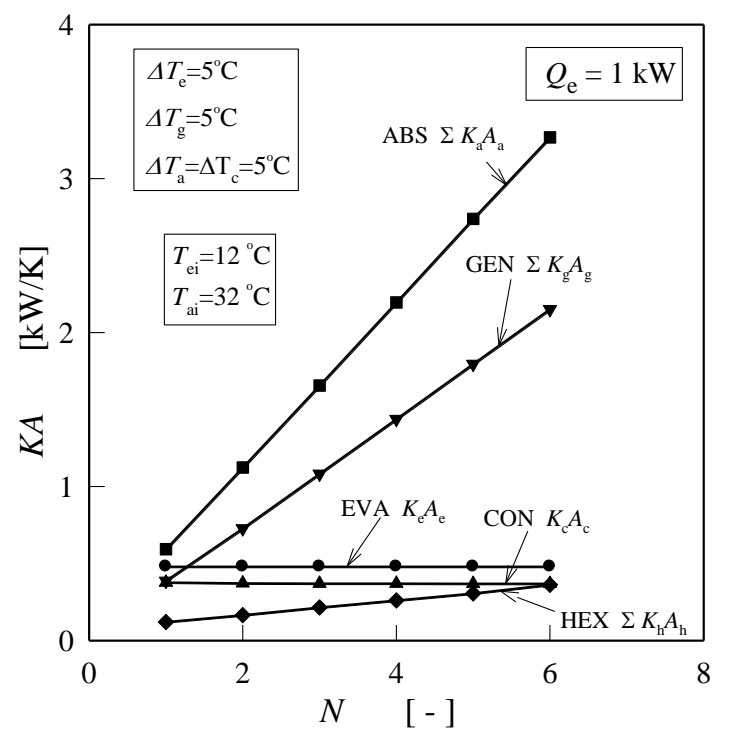

Fig.8 Characteristics of $K A$ values

図 8 は段数を増加させた場合における各要素の $K A$ 值を示したものである. 多段にするためにその段数分必要 となる吸収器, 再生器および溶液熱交換器の $K A$ 值はそれぞれ $\Sigma K_{\mathrm{a}} A_{\mathrm{a}}, \quad \sum K_{\mathrm{g}} A_{\mathrm{g}}$ および $\Sigma K_{\mathrm{h}} A_{\mathrm{h}}$ として合計值を示し ている. 図8からわかるように, 一つしかない蒸発器および凝縮器の $K A$ 值は段数が増加してもほとんど变化し ないのに対して, 吸収器, 再生器および溶液熱交換器ともに, 段数の増加に対してほぼ比例的に増大していくの がわかる。

図 6 で示したように，単効用を 2 段吸収にした場合，温水最低温度を $20.4 \sim 12.9^{\circ} \mathrm{C}$ もきく減少させることが 可能であるが， 2 段吸収から同じ程度の $K A$ 值を吸収器，再生器および溶液熱交換器に追加して 3 段吸収にした

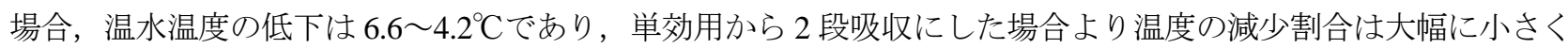
なる. さらに段数を増加させた場合, 温水最低温度の低下はしだいに限定的になっていく傾向にあることから, 多段にすることによって温水の最低温度をさらに低下させることは可能であるが，必要以上に段数を多くするこ とは実用上の観点から望ましくないことは容易に理解できる，しかしながら，吸収段数を増加させることによっ て，これまで未利用であった $40^{\circ} \mathrm{C}$ 以下の温水でさえも十分空調に利用可能であることを指摘できたことは低温水 吸收冷凍機の有効利用幅をさらに大きく広げ，地球規模の問題になっている $\mathrm{CO}_{2}$ 削減に対しても大いに貢献でき る可能性を与えることができたと考えている.

\section{6. 結 言}

吸收冷凍機の限界設計を考えた場合, 各要素の設計で用いられている対数平均温度差を与える二つの温度差の うち，小さくなるほうの温度差に対して，設計上の最小限界值を設定する方法が極めて効果的であることをすで に提示した．この新しい発想に基づく新アルゴリズムを多段吸収を用いた低温水吸収冷凍機に適用してサイクル シミュレーションを行い，空調に利用できる温水の最低温度およびその条件を明らかにした，得られた主な結果 は以下の通りである.

(1) 単効用低温水吸収冷凍機において, 冷水, 冷却水, 温水の温度差をすべて $5^{\circ} \mathrm{C} と し$, 冷却水を凝縮器と吸収 器に並列で導入して吸収液の循環量を変化させた場合, $C O P$ が大きく温水温度が最低となる条件は吸収器に 入ってくる濃吸収液の平衡温度と吸収器の出口における希吸収液の平衡温度との差が冷却水の出入口温度差 
と同じになる場合である.

（2）多段吸収を用いた低温水吸収冷凍機のサイクルシミュレーションを行った結果，冷却水入口温度の低下ある いは冷水入口温度の上昇に伴い吸収段数の限界が顕在化した。

(3) 理論上の無限段吸収が成立する条件はすべての吸収器出口における希吸収液の温度が凝縮器における飽和温 度と一致する場合であり, 理論上利用できる最低温水温度は凝縮器への冷却水入口温度に凝縮器の冷却水出 入口温度差, 凝縮器の最小温度差, 吸収器の冷却水出入口温度差および再生器の最小温度差を合計した值と なる。

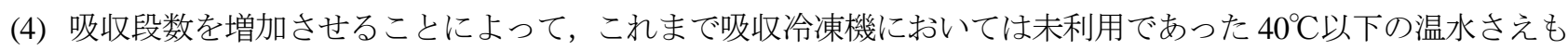
十分空調に利用可能であることが確認できた.

\section{文献}

江崎秀司, 伊良皆数恭, 小林崇浩, 大能正之, 金子敏之, 曽我孝, 低温水吸収冷凍機のサイクルシミュレーショ ン一第 1 報 : 新しいアルゴリズムを導入した温水の下限温度特性一, 日本冷凍空調学会論文集, Vol.28, No.2 (2011a), pp.149-160.

江崎秀司，伊良皆数恭，小林崇浩，大能正之，金子敏之，曽我孝，低温水吸収冷凍機のサイクルシミュレーショ ン一第 2 報 : 二段吸収を用いた超低温水の下限温度特性一, 日本冷凍空調学会論文集, Vol.28, No.4 (2011b), pp.341-352.

飛原英治，山本祐司，斎藤孝基，永岡義一，西山教之，二重効用吸収冷凍機のモデル化と制御一第 1 報 静特性 のモデル化一，日本冷凍協会論文集, Vol.4, No.2 (1987), pp.45-53.

井上修行, 入江智芳, 齋藤潔, 河合素直, 多重効用サイクルによる吸収冷凍機の高効率化一第 1 報 : 三重効用サ イクル—， 日本冷凍空調学会論文集, Vol.20, No.4 (2003), pp.461-472.

Kaita, Y., Simulation results of triple-effect absorption cycles, International Journal of Refrigeration, Vol.25 (2002), pp.999-1007.

川上隆一郎, 福知徹, 改田義雄, 二重効用吸収冷凍機の部分負荷特性, 日本冷凍空調学会論文集, Vol.21, No.3 (2004), pp.215-225.

君島真仁，葈谷至誠，植草常雄，河合素直，リン酸型燃料電池の排熱による吸収冷凍機の駆動に関する考察，日 本冷凍空調学会論文集, Vol.17, No.3 (2000), pp.285-296.

黒沢茂吉，横山武，柏木孝夫，T-s 線図による吸収冷凍サイクルの熱力学的解析，日本冷凍協会論文集, Vol.6, No.3 (1989), pp.45-56.

Mcneely, L., A., Thermodynamic properties of aqueous solutions of lithium bromide, American Society of Heating, Refrigerating and Air-Conditioning Engineers, PH-79-3, No.3 (1979), pp.413-434.

大園俊朗，吸収冷凍機の省エネルギー特性，冷凍, Vol.55, No.629 (1980), pp.49-59.

斎藤潔, 五十嵐洋晃, 河合素直, 二重効用吸収冷凍機の吸収サイクルの構成法がその特性に与える影響の検討, 日本機械学会論文集 B 編 , Vol.62, No.595 (1996), pp.1193-1199.

斉藤潔，菅野直紀，河合素直，西山教之，本間立，脇水広記，二熱源駆動吸収冷凍機の特性解析（第 1 報，低温 熱源が温水，高温熱源が水蒸気の場合)，日本機械学会論文集 B 編, Vol.60, No.573 (1994), pp.1770-1777.

設楽敦，臭化リチウムー水系二重効用吸収サイクルの高効率化に関する研究，日本冷凍空調学会論文集，Vol.17, No.3 (2000), pp.257-268.

Vilety, G., C., Lawson, M.B., and Lithgow R.A., Water-lithium bromide double-effect absorption cooling cycle analysis, American Society of Heating, Refrigerating and Air-Conditioning Engineers, HO-82-5, No.2 (1982), pp.811-823.

\section{References}

Esaki, S., Iramina, K., Kobayashi, T., Ohnou, M., Kaneko, T. and Soga, T., Cycle simulation of hot water fired absorption chiller - 1st Report: Lower limit characteristics of hot water temperature using a new solution algorithm-, Transactions of the Japan Society of Refrigerating and Engineers, Vol.28, No.2 (2011a), pp.149-160 (in Japanese).

Esaki, S., Iramina, K., Kobayashi, T., Ohnou, M., Kaneko, T. and Soga, T., Cycle simulation of hot water fired absorption chiller -2nd Report: Lower limit characteristics of hot water temperature using two-stage absorption-, Transactions 
of the Japan Society of Refrigerating and Engineers, Vol.28, No.4 (2011b), pp.341-352 (in Japanese).

Hihara, E., Yamamoto, Y., Saito, T., Nagaoka, Y. and Nishiyama, N., Modeling and control of a double-effect absorption refrigerating machine -1 st Report : Modeling of the static characteristics - , Transactions of the Japanese Association of Refrigeration, Vol.4, No.2 (1987), pp.45-53 (in Japanese).

Inoue, N., Irie, T., Saito, K. and Kawai, S., Study on high efficient absorption refrigerator using multi-effect cycle - 1st Report : Triple effect cycle-, Transactions of the Japan Society of Refrigerating and Engineers, Vol.20, No.4 (2003), pp.461-472 (in Japanese).

Kaita, Y., Simulation results of triple-effect absorption cycles, International Journal of Refrigeration, Vol.25 (2002), pp.999-1007.

Kawakami, R., Fukuchi, T. and Kaita, Y., Study on the partial load characteristics of double-effect absorption system, Transactions of the Japan Society of Refrigerating and Engineers, Vol.21, No.3 (2004), pp.215-225 (in Japanese).

Kimijima, S., Waragai, S., Uekusa, T. and Kawai, S., Investigation regarding the operation of absorption refrigerator using waste heat of phosphoric acid fuel cell, Transactions of the Japan Society of Refrigerating and Engineers, Vol.17, No.3 (2000), pp.285-296 (in Japanese).

Kurosawa, S., Yokoyama, T. and Kashiwagi, T., Thermodynamic analysis of absorption refrigerating cycle by T-s diagram, Transactions of the Japanese Association of Refrigeration, Vol.6, No.3 (1989), pp.45-56 (in Japanese).

Mcneely, L., A., Thermodynamic properties of aqueous solutions of lithium bromide, American Society of Heating, Refrigerating and Air-Conditioning Engineers, PH-79-3, No.3 (1979), pp.413-434.

Ohzono, T., The characteristics of absorption refrigerator on energy saving, Refrigeration, Vol.55, No.629 (1980), pp.49-59 (in Japanese).

Saito, K., Igarashi, H. and Kawai S., Study on the effect of the difference of absorption cycles on the characteristics of double-effect absorption refrigerator, Transactions of the Japan Society of Mechanical Engineers, Series B, Vol.62, No.595 (1996), pp.1193-1199 (in Japanese).

Saito, K., Sugano, N., Kawai, S., Nishiyama, N., Homma, R. and Wakimizu H., Studies on the characteristics of absorption refrigerator driven by two different heat sources (1st Report, Hot water and steam), Transactions of the Japan Society of Mechanical Engineers, Series B, Vol.60, No.573 (1994), pp.1770-1777 (in Japanese).

Shitara, A., Improvement of the COP of the LiBr-water double-effect absorption cycles, Transactions of the Japan Society of Refrigerating and Engineers, Vol.17, No.3 (2000), pp.257-268 (in Japanese).

Vilety, G., C., Lawson, M.B., and Lithgow R.A., Water-lithium bromide double-effect absorption cooling cycle analysis, American Society of Heating, Refrigerating and Air-Conditioning Engineers, HO-82-5, No.2 (1982), pp.811-823. 